\section{RMD Open}

Rheumatic \&

Musculoskeletal Diseases

To cite: Cutolo M, Paolino S, Smith V. Evidences for a protective role of vitamin $\mathrm{D}$ in COVID-19. RMD Open 2020;6:e001454. doi:10.1136/ rmdopen-2020-001454

Received 18 September 2020 Revised 16 November 2020 Accepted 19 November 2020

D Check for updates

(c) Author(s) (or their employer(s)) 2020. Re-use permitted under CC BY-NC. No commercial re-use. See rights and permissions. Published by BMJ.

${ }^{1}$ Laboratory of Experimental Rheumatology and Division of Rheumatology, University of Genoa, Genova, Liguria, Italy ${ }^{2}$ Clinical Rheumatology Unit, IRCCS San Martino Polyclinic Hospital, Genova, Italy ${ }^{3}$ Department of Rheumatology, Ghent University Hospital, Ghent, Belgium

${ }^{4}$ Department of Internal Medicine, Ghent University, Ghent, Belgium

Correspondence to Professor Maurizio Cutolo; mcutolo@unige.it

\title{
Evidences for a protective role of vitamin D in COVID-19
}

\author{
Maurizio Cutolo (D) , ${ }^{1,2}$ Sabrina Paolino, ${ }^{1}$ Vanessa Smith ${ }^{3,4}$
}

\section{INTRODUCTION}

\section{Vitamin D and COVID-19}

A growing number of concordant reports support a protective role for vitamin $\mathrm{D}$ in reducing at least the risk/severity of respiratory tract infections (RTIs), especially in the influenza and COVID-19 context. ${ }^{1-5}$

Major clinical reports show that vitamin D deficiency contribute to acute respiratory distress syndrome (ARDS) SARS-CoV-2 and that case-fatality rates increase with age and the highest SARS-CoV-2 serum concentrations. ${ }^{67}$

In addition, the outbreak of COVID-19 seems to occur mainly in the cold winter time, when serum 25-hydroxyvitamin D $(25(\mathrm{OH})$ D-calcidiol or calcifediol) concentrations are the lowest, as well as the ultraviolet B (UVB) doses, whereas the number of cases in the Southern Hemisphere near the end of summer are lower. ${ }^{8}$ -

Targeted $25(\mathrm{OH}) \mathrm{D}$ serum concentration measurements and vitamin D supplementation is strongly suggested have important patient and public health benefits. ${ }^{9}$ The positive role of vitamin $\mathrm{D}$ replacement therapy (vDRT) in reducing risk and severity in COVID-19 patients is supported by several clinical evidences and RCTs are undergoing, however, previous experiences of RCT related to vDRT are available from other lung viral infection studies and even in mechanically ventilated adult intensive care unit (ICU) patients. ${ }^{10-14}$

These important observations are corroborated by several biological/molecular mechanisms through vitamin $\mathrm{D}$ can generally reduce risk of infections and downregulate the immune/inflammatory reaction. Indeed, functional vitamin $\mathrm{D}$ receptors (VDR) are highly-expressed in B-lymphocytes and T-lymphocytes and mainly in monocytes/macrophages, justifying a role in modulating both innate and adaptive immune responses ${ }^{15-18}$ (figure 1).
We will analyse and discuss such available clinical evidences on the light of vitamin D molecular actions and the need to supplementation in COVID-19 patients.

Vitamin $\mathbf{D}$ is a steroidal hormone ( $\mathrm{D}$ hormone) and may influence the immune response in COVID-19

Vitamin D enters the body through dietary consumption (about 20\% of vitamin D3) or is synthesised by the skin $(80 \%)$ from 7-dihydro-cholesterol (provitamin D or chlecalciferol) after exposure to type B ultraviolet (UVB) which varies seasonally (figure 1 ).

The discovered presence of the VDR in activated $\mathrm{T}$ cells and monocytes, first suggested in 1983 that vitamin $\mathrm{D}$ may have a role in the function of the immune system. ${ }^{19}$

As matter of fact, vitamin $\mathrm{D}$ has received increased worldwide attention for its involvement in reducing risk for several chronic diseases, besides infectious diseases, including type 1 diabetes and notably autoimmune rheumatic diseases for the reason that may interfere with the immune system. ${ }^{20}$

The biological/molecular evidence for the interactions of vitamin $\mathrm{D}$ with the immune response is that its final active metabolite, namely calcitriol $(1,25(\mathrm{OH}) 2 \mathrm{D} 3)$, due to its structural origin from cholesterol, is molecularly considered a steroid hormone (D-hormone) like others (ie, sex hormones, cortisol) and analogously to glucocorticoids (and sex hormones) can exerts immunomodulatory/ antinflammatory activities through functional cell steroid receptors ${ }^{21-23}$ (figure 1).

Furthermore, the intensity and quality of the host immune/inflammatory response seems to influence the clinical severity and mortality risk associated with viral diseases (such as influenza and COVID-19) rather than the viral pathogen itself. ${ }^{24} 25$

Consequently, it is biologically plausible that $1,25(\mathrm{OH}) 2 \mathrm{D} 3$ may exert immunomodulatory effects also in COVID-19 patients, 


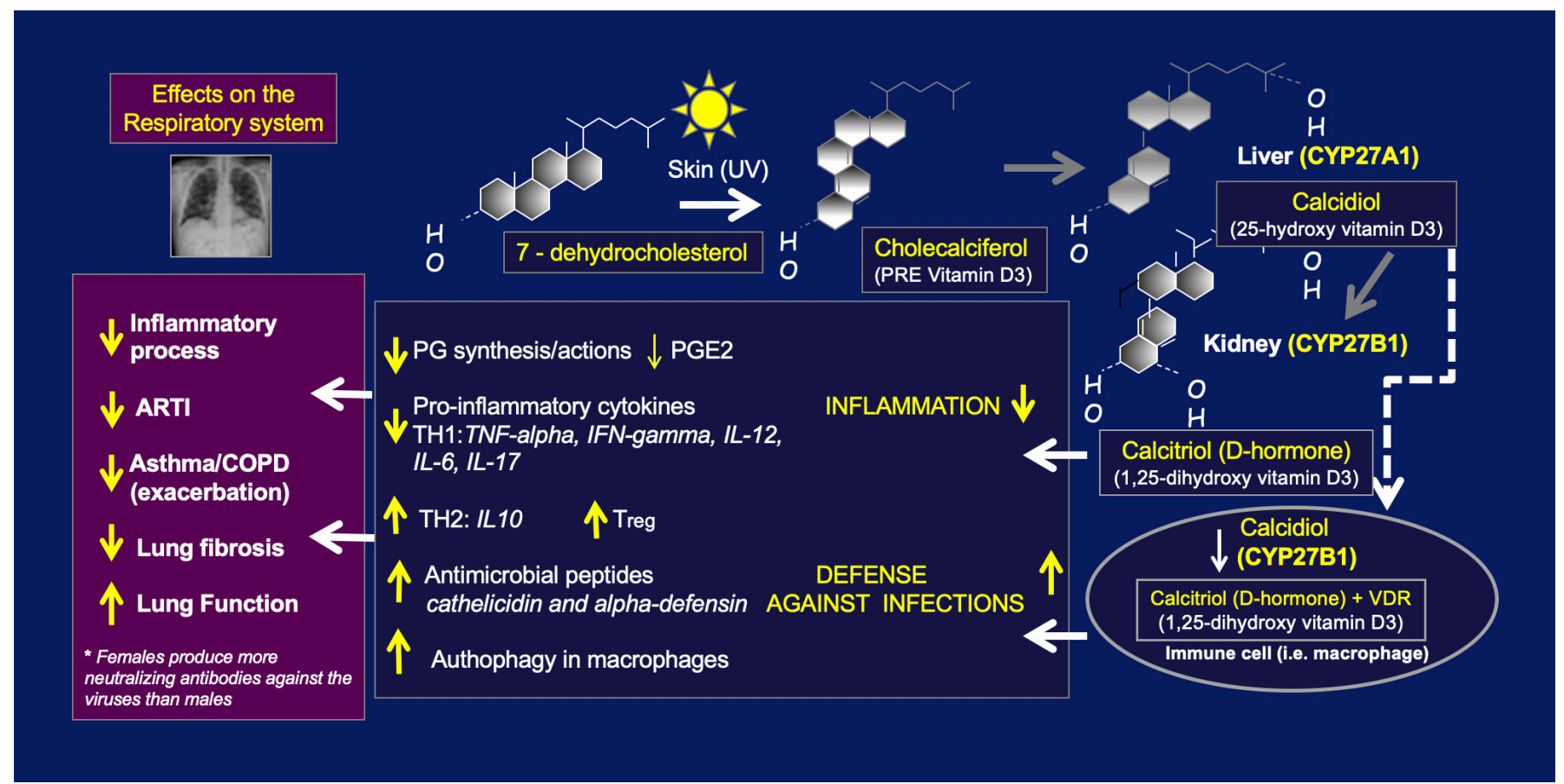

Figure 1 Proposed mechanism whereby 1,25(OH) D -VDR (D-hormone) signalling acts on the respiratory system during the COVID-19 infection. 1,25(OH) D, 1,25-hydroxyvitamin D; ARTI, acute respiratory tract infection; IFN-gamma, inteferon gamma; IL-6, inteleukin 6; IL10, interleukin; IL -12, interleukin 12; IL-17, interleukin 17; Treg, T regulatory cells; TNF, tumour necrosis factor; UV, ultraviolet; VDR, vitamin D receptor.

playing a role in the regulation of both innate and adaptive immunity. ${ }^{26}$

The intracellular conversion of $25(\mathrm{OH}) \mathrm{D}$ (calcidiol or calcifediol) into the active metabolite $1,25(\mathrm{OH}) 2 \mathrm{D} 3$, (calcitriol), through the intracrine actions of the enzyme 1-alpha-hydroxylase (CYP27B1), is distinct from the $1,25(\mathrm{OH}) 2 \mathrm{D} 3$ produced in kidneys and released into the systemic circulation; however, both have autocrine and paracrine functions that enhance host immunity, for example, by upregulating the antimicrobial peptides cathelicidin and alpha-defensin ${ }^{26}$ (figure 1).

In addition, the lung epithelium also expresses the VDR and CYP27B1 and may be an important target tissue for the vitamin $\mathrm{D}$ endocrine system. ${ }^{27}$

Innate immunity is the first line of defence against bacteria and viruses and is activated within hours of exposure to the pathogen.

Calcitriol (1,25 (OH)2D3) can inhibit inflammatory $\mathrm{T}$ cell cytokines such as interleukin (IL)-2 and IL-17 and toll-like receptors present on monocytes ${ }^{29}$ (figure 1).

On the other hands, in response to calcitriol administration, Th cells in an inflammatory environment they exhibit an enhanced potential for Th2 polarisation along with a decreased potential for Th17 polarisation. ${ }^{30}$

High doses of calcitriol supplementation in healthy human subjects ( $1 \mu \mathrm{g}$ two times per day for 7 days) leads to a dramatic reduction in the levels of proinflammatory cytokine IL-6, secreted by peripheral mononuclear cells. ${ }^{31}$

All these effects likely combine and translate in the induction of potential regulatory $\mathrm{T}$ cells, which are important for regulating immune responses and for the development of autoreactivity ${ }^{32}$ (figure 1).

Adaptive immunity is the immune process by which immunological memory to a specific antigen is established and requires a timeline much slower than innate immunity. Adaptive immunity is further mediated through two types of lymphocytic cells: $\mathrm{T}$ cells for cellmediated immunity and $\mathrm{B}$ cells that are responsible for humoral immunity. Activated B cells produce specific antibodies to the pathogen and neutralise or destroy it through a variety of mechanisms.

Calcitriol has been shown to suppress adaptive immunity in animal models, however, recent data are not yet sufficient to prove a real role for vitamin $\mathrm{D}$ in the modulation of adaptive immune system in humans, ${ }^{33}$

Lastly, the 'cytokine storm' is a term used to describe a hyperactive immune response to COVID-19. Although much yet to learnt about the pathophysiology of 'cytokine storm', it is considered to be mediated by the activation of the innate immune system and with an overly increased activation of the adaptive immunity. ${ }^{345}$

The clinical manifestations of this acute reaction include critical lung injury, wide-spread tissue damage, multiorgan failure and frequently death.

Regarding vitamin D and gender, it is known that mortality is higher in COVID-19 male than female patients, possibly because, due to androgens, the adaptive immune response in men is less efficient to mount an antibody response (against SARS-CoV-2), with the result that their disease further evolves severely ${ }^{36}$ (figure 1). 
On the contrary, female COVID-19 patients react immunologically better due to enhancing estrogenic effects on adaptive immunity, with the result to produce specific antibodies that may neutralise earlier the virus, like what happen with other infections and after vaccinations. ${ }^{37}$

Interestingly, it has been reported that in severe COVID-19 patients, the average of SARS- CoV-2 IgG antibody serum concentrations in women tended to be higher and the generation of IgG antibody was stronger in female than male patients. ${ }^{38}$

Therefore, vitamin D deficiency, seems to add further risks to the male COVID-19 patients, in fact concentrations of $25(\mathrm{OH}) \mathrm{D}$, have been found significantly lower only in male patients COVID-19 vs women and controls $(\mathrm{p}=0.0006)$ and were not confounded by vitamin D-impacted comorbidities and seasonality. Conclusion, vitamin $\mathrm{D}$ deficiency seems a prevalent and further risk factor for severe COVID-19 male patients. ${ }^{39}$

\section{Vitamin D and RTIs: Iesson from the recent experience}

The seasonality of viral RTIs such as those caused by influenza virus and rhinovirus has been recognised from long time and is even considered to be one of the major contributor to seasonal variations in human mortality. ${ }^{40}$

As matter of fact, a recent large study found that sunlight UV radiation dose is negatively correlated with the percent positive patients for SARS-CoV-2 and for four other common human coronaviruses in the USA, and this association is season-related with lowest vitamin D serum concentrations. ${ }^{41}$

In a large population survey (6789 participants), the prevalence of RTIs and altered lung function showed a strong seasonal pattern and linear association in the opposite direction to the vitamin $\mathrm{D}$ serum concentrations. ${ }^{42}$

A more detailed study evaluating the link between vitamin $\mathrm{D}$ concentrations and ARDS, patients with $25(\mathrm{OH}) \mathrm{D} 3<20 \mathrm{ng} / \mathrm{mL}$ showed a significantly higher odds of ARDS compared with patients with $25(\mathrm{OH}) \mathrm{D}$ $>20 \mathrm{ng} / \mathrm{mL}$ after adjustment for age, gender, diagnostic category, staging and degree of cigarette consumption, $(\mathrm{p}=0.032)^{7}$

Interestingly, when $25(\mathrm{OH}) \mathrm{D}$ concentrations were analysed with logistic regression as a continuous exposure in $0.4 \mathrm{ng} / \mathrm{mL}$ increments, the odds of ARDS decreased by $17 \%$ for every $0.4 \mathrm{ng} / \mathrm{mL}$ increase in $25(\mathrm{OH}) \mathrm{D}(\mathrm{OR} 0.83$ (95\% CI 0.69 to $0.98 ; \mathrm{p}=0.033){ }^{7}$

In another study, it was found that each $4 \mathrm{ng} / \mathrm{mL}$ increase in $25(\mathrm{OH}) \mathrm{D}$ was associated with a $7 \%$ lower risk of lung infection (95\% CI 3\% to $11 \%$ ) after adjustment for lifestyle, socioeconomic factors and adiposity. ${ }^{42}$

Therefore, it has been argued that vitamin D status should be taken into account as an important contributor in determining the population susceptibility to seasonal epidemic outbreaks, together with the effects of augmented indoor confinement in wintertime (ie, school) and increased circulating reservoirs of respiratory viruses. ${ }^{43}$
Furthermore, another large observational study evaluating healthy adults during the fall and winter of 2009-2010, investigated the relationship between serum $25(\mathrm{OH}) \mathrm{D}$ concentrations and incidence of acute RTIs (ARTIs). ${ }^{44}$

The result was that only $17 \%$ of patients showing serum $25(\mathrm{OH}) \mathrm{D}$ concentrations over $38 \mathrm{ng} / \mathrm{mL}$ throughout the study developed ARTIs, on the contrary $45 \%$ of those with serum concentrations less than $38 \mathrm{ng} / \mathrm{mL}$ did.

Concentrations of vitamin D over $40 \mathrm{ng} / \mathrm{mL}$ induced a significant $(\mathrm{p}<0.0001)$ twofold reduction in risk of developing ARTIs including a strong reduction in the percentage of days of illness (figure 1).

The negative correlation between seasonality (winter) of inflammatory conditions (ie, rheumatoid arthritis) and vitamin D concentrations (UV effects) has been already deeply analysed and it links the immune response with the $25(\mathrm{OH}) \mathrm{D}$ concentrations. ${ }^{45} 46$

More recently, the prevalence of vitamin D insufficiency and deficiency, (serum concentrations of 12-20 and $<12 \mathrm{ng} / \mathrm{mL}$, respectively), was assessed in association with mortality from respiratory diseases during 15 years of follow-up in a cohort of 9548 adults, aged $50-75$ years. ${ }^{47}$

Overall, $41 \%$ of respiratory disease mortality was statistically attributable to vitamin $\mathrm{D}$ insufficiency or deficiency.

Previously, in a systematic review and meta-analysis, 25 randomised, double blind, placebo controlled trials (total 11321 participants, aged 0-95 years) were selected in order to evaluate if supplementation of vitamin D might reduce the risk of ARTIs. ${ }^{48}$

Interestingly, vitamin D supplementation reduced significantly the risk of ARTI among all participants $(\mathrm{p}<0.001)$ and in a subgroup analysis, protective effects against ARTIs were observed in those individuals receiving daily or weekly vitamin $\mathrm{D}$ without additional bolus doses, but not in those receiving one or more bolus doses $(p=0.05)$. Among those receiving daily or weekly vitamin $\mathrm{D}$, protective effects were stronger in those with baseline $25(\mathrm{OH}) \mathrm{D}<10 \mathrm{ng} / \mathrm{mL}$ than in those with baseline $25(\mathrm{OH}) \mathrm{D}$ levels $\geq 10 \mathrm{ng} / \mathrm{mL}$ (for interaction $\mathrm{p}=0.006$ ). The lesson from these recent evidences seem to confirm that vitamin D supplementation is safe and might protect at least against ARTIs overall. ${ }^{49}$

This experience seems today replicated in COVID-19 patients.

\section{Clinical evidences for vitamin D involvement in COVID-19 and} earliest therapeutical interventions

SARS-CoV-2 is the major allmark of COVID-19, with clinical outcomes ranging from mild to severe, including death.

The most recent evidences support the clinical experience that vitamin $\mathrm{D}$ supplementation would be advantageous in the treatment of COVID-19 patients, in reducing the presence of SARS-CoV-2 at the level of the upper respiratory tract, in making the patients less infectious (justifying the presence of negative PCR in people 
with higher $25(\mathrm{OH}) \mathrm{D})$ and in preventing a more severe symptomatology. ${ }^{2}$

On the other hands, a very recent study, showed the first direct evidence of the association between vitamin D deficiency and potentially insufficient treatment with testing positive for COVID-19. ${ }^{50}$

The multivariable analysis suggested that individuals with most recent vitamin D deficiency whose treatments were not increased (remained vitamin D deficient), were at higher risk of testing positive for COVID-19, than were individuals with serum concentrations that were likely to be sufficient confirming the majority of reports. ${ }^{51}$

In addition, a very recent small study showed that $84.6 \%$ of intensive treatment unit (ITU) severe COVID-19 patients had deficiency of vitamin D $(<12 \mathrm{ng} / \mathrm{mL})$ compared with only $57.1 \%$ of patients on medical ward. ${ }^{51}$

Similar results were confirmed in another study in which serum $25(\mathrm{OH}) \mathrm{D}$ concentrations were evaluated in 134 inpatients with positive SARS-CoV-2 swab or clinic-radiological diagnosis of COVID-19. ${ }^{2}$ Again, ITU COVID-19 patients showed lower $25(\mathrm{OH}) \mathrm{D}$ serum concentrations compared with non-ITU patients despite being younger, $(13.4 \mathrm{ng} / \mathrm{mL} \pm 6.7$ vs. non-ITU: $19.4 \mathrm{ng} /$ $\mathrm{mL} \pm 15.3 ; \mathrm{p}=0.03)$.

Nevertheless, ITU COVID-19 patients showed a significantly higher prevalence of vitamin $\mathrm{D}$ deficiency, with only $19 \%$ being vitamin D replete compared with $39.1 \%$ of non-ITU patients $(\mathrm{p}=0.02)$. However, serum $25(\mathrm{OH})$ $\mathrm{D}$ concentrations were not associated with mortality ( $\mathrm{p}=0.94$ ) probably due to the short time of observation.

These results suggest the acute and follow-up assessment of serum 25(OH)D concentrations during COVID-19 admission.

Another study, among patients with vitamin D deficiency, further confirmed higher incidence of noninvasive ventilation support and high-dependency unit admission $(\mathrm{p}=0.042)$, with older COVID-19 adults demonstrating worse morbidity outcomes. Again the vitamin D status may be considered at least an useful prognosticator. ${ }^{52}$

A number of investigations confirm that deficient/ insufficient concentrations of vitamin $\mathrm{D}$ are associated with the hospitalisation of COVID-19 patients, and less than $16 \mathrm{ng} / \mathrm{mL}$ values of the serum vitamin $\mathrm{D}$ have been reported to be possibly associated even with increased risk of sepsis in critically ill patients. ${ }^{53} 54$

A large Israeli studied cohort, proved that, low serum $25(\mathrm{OH}) \mathrm{D}$ concentrations almost doubled the risk for hospitalisation due to the COVID-19 infection. ${ }^{55}$

Finally, in a very recent case-control study, the serum $25(\mathrm{OH}) \mathrm{D}$ concentration in COVID-19 patient was found the lowest in severe/criticalcases, compared with mild cases. Severe/critical COVID-19 cases were significantly older and had higher percentages of comorbidity (renal failure) compared with mild cases, however, the statistically significant associations remained even after controlling for demographics and comorbidities. ${ }^{56}$

Of course, the majority of these studies has aimed to correct the results from concomitant risk factors for vitamin D deficiency, but a residual confounding is still always possible. In fact, factors associated with worse COVID-19 prognosis include old age, ethnicity, male sex, socioeconomic level, as well as comorbidities like obesity, diabetes and hypertension, and all of these also associate with deficiency of vitamin $\mathrm{D} .^{57}$

Therefore, the absence of specific treatment for COVID-19 generated many trials, but so far without final guide lines, the same holds true for testing the potential benefits of vitamin $\mathrm{D}$ supplementation of patients with SARS-CoV-2 infections. ${ }^{58}$

Interesting a pilot RCT published in October 2020, demonstrated that administration of a high dose of Calcifediol $(25(\mathrm{OH}) \mathrm{D})$, significantly reduced the need for ICU treatment of patients requiring hospitalisation due to proven COVID-19. ${ }^{59}$

At the same time, in a clinical cases series report, COVID-19 patients who received a high dose of vitamin D supplementation, they achieved normalisation of vitamin D serum concentrations and improved clinical recovery, evidenced by decrease in inflammatory biomarker status, lower oxygen requirements and finally less days of hospitalisation. ${ }^{60}$

In addition, it has been already published a pragmatic trial design that will allow parallel testing of vitamin D3 supplementation for early treatment and postexposure prophylaxis of COVID- $19 .{ }^{61}$

To conclude, according to National Institute of Health (NIH) Trialnet database, several observational and intervention studies, including some RCT, are running and should provide guidelines within a few months. ${ }^{6263}$

In essence, the rationale for intervention studies with vitamin $\mathrm{D}$ in cOVID-19 patients, isfocused on the ability of $1,25(\mathrm{OH}) 2 \mathrm{D} 3$ to activate the native immune defence system, while reducing the proinflammatory cytokine production and tapering down the acquired immune system. ${ }^{64}$

In addition, as discussed previously in this text, vitamin $\mathrm{D}$ deficiency may predispose to increased risk of infections including SARS-CoV-2, and its supplementation may decrease the risk of upper respiratory infections.

\section{How to supplement vitamin D in COVID-19 patients with deficiency}

Although the degree of protection generally increases as $25(\mathrm{OH}) \mathrm{D}$ serum concentration increases, the optimal range is considered to be in the range of $40-60 \mathrm{ng} / \mathrm{mL}$ $(100-150 \mathrm{nmol} / \mathrm{L})$. In order achieve those levels, approximately half the population should take at least 2000$5000 \mathrm{IU} /$ day of vitamin D. ${ }^{65}$

The supplementation with calcidiol $(25(\mathrm{OH}) \mathrm{D})$ may present some advantages over the native vitamin $\mathrm{D}$ (cholecalciferol), in fact, calcidiol has a more reliable intestinal absorption (close to 100\%) and its administration can rapidly restore serum concentrations of $25 \mathrm{OHD}$ as it does not require hepatic 25-hydroxylation (CYP27A1) (figure 1). 
This is especially relevant in clinical situations whereby rapid restoration of serum 25OHD is desirable and expression is compromised. Such impaired hepatic vitamin D hydroxylation by cytochrome p450 2R1 (CYP2R1) activity has been well demonstrated in several animal models of obesity, diabetes or glucocorticoid excess and in patients with COPD or asthma. ${ }^{66}$

Various loading doses have been studied for achieving a $25(\mathrm{OH}) \mathrm{D}$ concentration of $30 \mathrm{ng} / \mathrm{mL}$. For example, one study used a weekly or fortnightly dose totaling $100000-200000 \mathrm{IU}$ over 8 weeks (1800 or $3600 \mathrm{IU} /$ day) ${ }^{67}$

Clinical data suggest that daily or weekly doses offer better results than bolus in the protection against acute pulmonary infections and supplementation with extremely high doses of vitamin $\mathrm{D}$ could be harmful and toxic, especially to elderly individuals. ${ }^{68} 69$

Some reports just speculated on single high vitamin D doses and mechanisms for prevention and treatment of COVID-19 patients. $^{70}$

Therefore, the supplementation of vitamin $\mathrm{D}$ by bolus or extremely high doses (ie, 600000 UI single dose oral dose) should be avoided since can increase the risk of intoxication without evidence of benefits at least in COVID-19 patients. ${ }^{65}$

In addition, from the literature, for healthy individuals, it is suggested taking $10000 \mathrm{IU} /$ day for a month, which is effective in rapidly increasing serum concentrations of $25(\mathrm{OH}) \mathrm{D}$ into the optimal range of $40-60 \mathrm{ng} / \mathrm{mL}^{10}$

To maintain that level after that first month, the dose can be decreased to almost 2000-3000 IU/day.

However, measuring serum $25(\mathrm{OH}) \mathrm{D}$ concentration would be useful to determine baseline and the achieved $25(\mathrm{OH}) \mathrm{D}$ concentrations.

Patients hospitalised with COVID-19 should have baseline serum $25(\mathrm{OH}) \mathrm{D}$ concentrations measured and must be supplemented at least to a level $\geq 30 \mathrm{ng} / \mathrm{mL}$ (optimal $40-60)$, especially when the baseline level is $<10 \mathrm{ng} / \mathrm{mL}$ and such deficiency is significantly more present in male patients. ${ }^{71}$

In conclusion, we might suggest in COVID-19 patients with $25(\mathrm{OH}) \mathrm{D}$ serum levels under $20 \mathrm{ng} / \mathrm{mL}$ that the usual recommended dose for correction of deficiency should be 6000-7000 oral IU/day for the first 6-8 weeks. For maintenance, the dose should varies from 2000 to 3000 oral IU/day depending on the age and clinical condition of the patient up to achieve the suggested concentrations. $^{72}$

\section{CONCLUSIONS}

Given the evidence supporting the role of vitamin $\mathrm{D}$ in modulating immune function, and the impact of vitamin D supplementation on vitamin D-deficient patients with COVID-19, as well as the favourable safety profile (and low cost) of vitamin $\mathrm{D}$, practical recommendations should be synthesised as follows:
- Current public health guidelines for optimising vitamin D status should be followed always and clinical data from systematic reviews and meta-analyses show benefits in the prevention of respiratory infections and improvement of pulmonary function when vitamin D-deficient patients are supplemented.

- The optimal vitamin D status of the host may contribute key immunoregulatory functions in settings of viral respiratory infection and overall the altered immune-inflammatory COVID-19 reactivity at least by downregulating overly exuberant cytokine responses (pathological cytokine storm, in fact higher vitamin D levels correlate with lower IL-6 levels).

- Patients hospitalised with COVID-19 should have baseline serum $25(\mathrm{OH}) \mathrm{D}$ concentrations measured and should be supplemented to a level $>30 \mathrm{ng} / \mathrm{mL}$ (optimal 40-60 ng/mL), especially when the baseline level is $<10 \mathrm{ng} / \mathrm{mL}$.

- In COVID-19 patients with 25(OH)D serum concentrations under $20 \mathrm{ng} / \mathrm{mL}$ the recommended dose for correction of deficiency is $6000-7000$ oral IU/ day for $6-8$ weeks. For maintenance, the dose varies from 2000 to 3000 oral IU/day depending on the age and clinical condition of the individual up to reach optimal concentrations.

- When it is not possible to measure baseline $25(\mathrm{OH}) \mathrm{D}$ concentrations in COVID-19 patients, it seems essential supplementing with 2000-3000 oral IU per day up to the suggested optimal serum concentrations (40-60 ng/mL).

A final message based on all the practical issues discussed: keep the vitamin $\mathrm{D}$ serum concentrations during all the year between 40 and $60 \mathrm{ng} / \mathrm{mL}(100$ $150 \mathrm{nmol} / \mathrm{L}$ ), it is one of the fundamental care to reduce, at least the risk of RTIs, COVID-19 included.

Acknowledgements MC and SP are members of the EULAR Study Group on Neuroendocrine Immunology of Rheumatic Diseases (NEIRD). VS is a Senior Clinical Investigator of the Research Foundation-Flanders (Belgium) (FW0) [1.8.029.15N]. We thank Drs Greta Pacini, Carlotta Schenone, Emanuele Gotelli and Alberto Sulli contributed to the acquisition of data and Dr Sara De Gregorio who was involved in figure definition.

Contributors MC conceived and designed the study, wrote the draft and submitted the manuscript. SP and VS contributed to the acquisition of data, to the draft organisation and approved the final manuscript.

Funding The authors have not declared a specific grant for this research from any funding agency in the public, commercial or not-for-profit sectors.

Competing interests None declared.

Patient consent for publication Not required.

Provenance and peer review Not commissioned; internally peer reviewed.

Data availability statement For data availability, please contact Prof. M Cutolo.

Open access This is an open access article distributed in accordance with the Creative Commons Attribution Non Commercial (CC BY-NC 4.0) license, which permits others to distribute, remix, adapt, build upon this work non-commercially, and license their derivative works on different terms, provided the original work is properly cited, appropriate credit is given, any changes made indicated, and the use is non-commercial. See: http://creativecommons.org/licenses/by-nc/4.0/.

ORCID iD

Maurizio Cutolo http://orcid.org/0000-0002-5396-0932 


\section{REFERENCES}

1 Munshi R, Hussein MH, Toraih EA, et al. Vitamin D insufficiency as a potential culprit in critical COVID-19 patients. J Med Virol 2020:jmv.26360. doi:10.1002/jmv.26360

2 Panagiotou G, Tee SA, Ihsan Y, et al. Low serum 25-hydroxyvitamin $\mathrm{D}(25[\mathrm{OH}] \mathrm{D})$ levels in patients hospitalized with COVID-19 are associated with greater disease severity. Clin Endocrinol 2020. doi:10.1111/cen.14276

3 Ilie PC, Stefanescu S, Smith L. The role of vitamin D in the prevention of coronavirus disease 2019 infection and mortality. Aging Clin Exp Res 2020;32:1195-8.

4 Ginde AA, Mansbach JM, Camargo CA. Association between serum 25-hydroxyvitamin $D$ level and upper respiratory tract infection in the third National health and nutrition examination survey. Arch Intern Med 2009;169:384-90.

5 Science M, Maguire JL, Russell ML, et al. Low serum 25-hydroxyvitamin D level and risk of upper respiratory tract infection in children and adolescents. Clin Infect Dis 2013;57:392-7.

6 Vyas N, Kurian SJ, Bagchi D, et al. Vitamin D in prevention and treatment of COVID-19: current perspective and future prospects. J Am Coll Nutr 2020;1:1-14.

7 Dancer RCA, Parekh D, Lax S, et al. Vitamin D deficiency contributes directly to the acute respiratory distress syndrome (ARDS). Thorax 2015;70:617-24.

8 Rhodes JM, Subramanian S, Laird E, et al. Perspective: vitamin D deficiency and COVID-19 severity - plausibly linked by latitude, ethnicity, impacts on cytokines, ACE2 and thrombosis. J Intern Med 2020;113.

9 Grant WB, Al Anouti F, Moukayed M. Targeted 25-hydroxyvitamin D concentration measurements and vitamin $\mathrm{D}_{3}$ supplementation can have important patient and public health benefits. Eur J Clin Nutr 2020;74:366-76.

10 Grant WB, Lahore H, McDonnell SL, et al. Evidence that vitamin D supplementation could reduce risk of influenza and COVID-19 infections and deaths. Nutrients 2020;12:988.

11 National Library of Medicine (US). ClinicalTrials.gov [Internet.Apr 3Identifier NCT04334005. Bethesda (MD: National Library of Medicine (US), 2020.

12 clinicaltrials.gov. Effect of vitamin D administration on prevention and treatment of mild forms of suspected Covid-19 (COVITD-19), 2020. Available: https://clinicaltrials.gov/ct2/show/NCT04334005 [Accessed 13 Apr 2020].

13 Han JE, Jones JL, Tangpricha V, et al. High dose vitamin D administration in ventilated intensive care unit patients: a pilot double blind randomized controlled trial. J Clin Trans/ Endocrinol 2016;4:59-65.

14 Urashima M, Segawa T, Okazaki M, et al. Randomized trial of vitamin D supplementation to prevent seasonal influenza A in schoolchildren. Am J Clin Nutr 2010:91:1255-60.

15 Panfili FM, Roversi M, D'Argenio P, et al. Possible role of vitamin D in Covid-19 infection in pediatric population. J Endocrinol Invest 2020:1-9.

16 Mahon BD, Wittke A, Weaver V, et al. The targets of vitamin D depend on the differentiation and activation status of CD4 positive $T$ cells. J Cell Biochem 2003;89:922-32.

17 Zhang Y, Leung DYM, Richers BN, et al. Vitamin D inhibits monocyte/macrophage proinflammatory cytokine production by targeting MAPK phosphatase-1. J Immunol 2012;188:2127-35.

18 Chen S, Sims GP, Chen XX, et al. Modulatory effects of 1,25-dihydroxyvitamin D3 on human B cell differentiation. J Immunol 2007;179:1634-47.

19 Bhalla AK, Amento EP, Clemens TL, et al. Specific high-affinity receptors for 1,25-dihydroxyvitamin D3 in human peripheral blood mononuclear cells: presence in monocytes and induction in T Iymphocytes following activation. J Clin Endocrinol Metab 1983;57:1308-10.

20 Abrahamsen B, Harvey NC. The role of vitamin D supplementation in patients with rheumatic diseases. Nat Rev Rheumatol 2013:9:411-22.

21 Cutolo M, Otsa K, Paolino S, et al. Vitamin D involvement in rheumatoid arthritis and systemic lupus erythaematosus. Ann Rheum Dis 2009;68:446-7.

22 Cutolo M. Further emergent evidence for the vitamin D endocrine system involvement in autoimmune rheumatic disease risk and prognosis. Ann Rheum Dis 2013;72:473-5.

23 Cutolo M, Pizzorni C, Sulli A. Vitamin D endocrine system involvement in autoimmune rheumatic diseases. Autoimmun Rev 2011;11:84-7.

24 Kobasa D, Takada A, Shinya K, et al. Enhanced virulence of influenza A viruses with the haemagglutinin of the 1918 pandemic virus. Nature 2004:431:703-7.
25 Cheung CY, Poon LLM, Lau AS, et al. Induction of proinflammatory cytokines in human macrophages by influenza $A(H 5 N 1)$ viruses: a mechanism for the unusual severity of human disease? Lancet 2002;360:1831-7.

26 Bilezikian JP, Bikle D, Hewison M, et al. Mechanisms in endocrinology: vitamin D and COVID-19. Eur J Endocrinol 2020;183:R133-47.

27 Mathyssen C, Aelbrecht C, Serré J, et al. Local expression profiles of vitamin D-related genes in airways of COPD patients. Respir Res 2020;21:137.

28 Baeke F, Takiishi T, Korf H, et al. Vitamin D: modulator of the immune system. Curr Opin Pharmacol 2010;10:482-96.

29 Fawaz L, Mrad MF, Kazan JM, et al. Comparative effect of 25(OH) D3 and 1,25(OH)2D3 on Th17 cell differentiation. Clin Immunol 2016;166-167:59-71.

30 Chun-Sheng Bi CS, Li XX, Hong-Lei Qu HL, et al. Calcitriol inhibits osteoclastogenesis in an inflammatory environment by changing the proportion and function of T helper cells ubsets (Th2/Th17). Cell Prolif 2020;53:e1287

31 Müller K, Diamant M, Bendtzen K. Inhibition of production and function of interleukin- 6 by 1,25 -dihydroxyvitamin D3. Immunol Lett 1991;28:115-20.

32 Fisher SA, Rahimzadeh M, Brierley C, et al. The role of vitamin D in increasing circulating $T$ regulatory cell numbers and modulating $T$ regulatory cell phenotypes in patients with inflammatory disease or in healthy volunteers: a systematic review. PLoS One 2019;14:e0222313.

33 Sassi F, Tamone C, D'Amelio P. Vitamin D: nutrient, hormone, and immunomodulator. Nutrients 2018;10:1656.

34 Leisman DE, Ronner L, Pinotti R, et al. Cytokine elevation in severe and critical COVID-19: a rapid systematic review, meta-analysis, and comparison with other inflammatory syndromes. Lancet Respir Med 2020;8:1233-44

35 Ragab D, Salah Eldin H, Taeimah M, et al. The COVID-19 cytokine storm; what we know so far. Front Immunol 2020;11:1446.

36 Lipsky MS, Hung M. Men and COVID-19: a pathophysiologic review. Am J Mens Health 2020;14:1557988320954021.

37 Cutolo M, Smith V, Paolino S. Understanding immune effects of oestrogens to explain the reduced morbidity and mortality in female versus male COVID-19 patients. Comparisons with autoimmunity and vaccination. Clin Exp Rheumatol 2020;38:383-6.

38 Zeng F, Dai C, Cai P, et al. A comparison study of SARS-CoV-2 lgG antibody between male and female COVID-19 patients: a possible reason underlying different outcome between sex. J Med Virol 2020;92:2050-4.

39 La Vignera S, Cannarella R, Condorelli RA, et al. Sex-Specific SARSCoV-2 mortality: among Hormone-Modulated ACE2 expression, risk of venous thromboembolism and hypovitaminosis D. Int J Mol Sci 2020;21:ijms21082948. doi:10.3390/ijms21082948

40 Reichert TA, Simonsen L, Sharma A, et al. Influenza and the winter increase in mortality in the United States, 1959-1999. Am J Epidemiol 2004;160:492-502.

41 Tang L, Liu M, Ren B, et al. Sunlight ultraviolet radiation dose is negatively correlated with the percent positive of SARS-CoV-2 and four other common human coronaviruses in the U.S. Sci Total Environ 2021:751:141816.

42 Berry DJ, Hesketh K, Power C, et al. Vitamin D status has a linear association with seasonal infections and lung function in British adults. Br J Nutr 2011;106:1433-40.

43 Cannell JJ, Vieth R, Umhau JC, et al. Epidemic influenza and vitamin D. Epidemiol Infect 2006;134:1129-40.

44 Sabetta JR, DePetrillo P, Cipriani RJ, et al. Serum 25-hydroxyvitamin $D$ and the incidence of acute viral respiratory tract infections in healthy adults. PLoS One 2010;5:e11088.

45 Cutolo M. Solar light effects on onset/relapses and circannual/ circadian symptomatology in rheumatoid arthritis. Clin Exp Rheumatol 2003;21:148-50.

46 Cutolo M. Rheumatoid arthritis: circadian and circannual rhythms in RA. Nat Rev Rheumatol 2011;7:500-2.

47 Brenner H, Holleczek B, Schöttker B. Vitamin D insufficiency and deficiency and mortality from respiratory diseases in a cohort of older adults: potential for limiting the death Toll during and beyond the COVID-19 pandemic? Nutrients;12:E2488.

48 Martineau AR, Jolliffe DA, Hooper RL, et al. Vitamin D supplementation to prevent acute respiratory tract infections: systematic review and meta-analysis of individual participant data. BMJ 2017;356:i6583.

49 Siddiqui M, Manansala JS, Abdulrahman HA, et al. Immune modulatory effects of vitamin D on viral infections. Nutrients 2020;12:2879. doi:10.3390/nu12092879 
50 Meltzer DO, Best TJ, Zhang H, et al. Association of vitamin D deficiency and treatment with COVID-19 incidence. medRxiv 2020:05.08.20095893. doi:10.1101/2020.05.08.20095893

51 Allegra A, Tonacci A, Pioggia G, et al. Vitamin deficiency as risk factor for SARS-CoV-2 infection: correlation with susceptibility and prognosis. Eur Rev Med Pharmacol Sci 2020;24:9721-38.

52 Baktash V, Hosack T, Patel N, et al. Vitamin D status and outcomes for hospitalised older patients with COVID-19. Postgrad Med J 2020:postgradmedj-2020-138712. doi:10.1136/ postgradmedj-2020-138712

53 Mardani R, Alamdary A, Mousavi Nasab SD, et al. Association of vitamin $\mathrm{D}$ with the modulation of the disease severity in COVID-19. Virus Res 2020;289:198148.

54 Moromizato T, Litonjua AA, Braun AB, et al. Association of low serum 25-hydroxyvitamin D levels and sepsis in the critically ill. Crit Care Med 2014;42:97-107.

55 Merzon E, Tworowski D, Gorohovski A, et al. Low plasma $25(\mathrm{OH})$ vitamin $\mathrm{D}$ level is associated with increased risk of COVID-19 infection: an Israeli population-based study. Febs $J$ 2020;287:3693-702.

56 Ye K, Tang F, Liao X, et al. Does Serum Vitamin D Level Affect COVID-19 Infection and Its Severity?-A Case-Control Study. J Am Coll Nutr 2020:1-8.

57 Rhodes JM, Subramanian S, Laird E, et al. Perspective: Vitamin D deficiency and COVID-19 severity - plausibly linked by latitude, ethnicity, impacts on cytokines, ACE2 and thrombosis. J Intern Med 2020;2:oim.13149. doi:10.1111/joim.13149

58 Ho LP CW, Kalimuddin S, et al. Cohort study to evaluate effect of vitamin D, magnesium, and vitamin B 12 in combination on severe outcome progression in older patients with coronavirus (COVID-19). Nutrition 2020;8:111017:79-80.

59 Entrenas Castillo M, Entrenas Costa LM, Vaquero Barrios JM, et al. "Effect of calcifediol treatment and best available therapy versus best available therapy on intensive care unit admission and mortality among patients hospitalized for COVID-19: A pilot randomized clinical study". J Steroid Biochem Mol Biol 2020;203:105751.

60 Ohaegbulam KC, Swalih M, Patel P, et al. Vitamin D supplementation in COVID-19 patients: a clinical case series. Am J Ther 2020;27:e485-90.
61 Wang R, DeGruttola V, Lei Q, et al. The vitamin D for COVID-19 (vivid) trial: a pragmatic cluster-randomized design. Contemp Clin Trials 2020:106176.

62 ChiCTR. Impact of vitamin D deficiency on prognosis of patients with novel coronavirus pneumonia (COVID- 19), 2018. Available: http://www.chictr.org.cn/showprojen.aspx?proj=52006

63 (COVID-19). The relationship between vitamin $D$ and novel coronavirus pneumonia, 2018: 3-4. http://www.chictr.org.cn/ showprojen.aspx?proj=51390

64 Quesada-Gomez JM, Entrenas-Castillo M, Bouillon R. Vitamin D receptor stimulation to reduce acute respiratory distress syndrome (ARDS) in patients with coronavirus SARS-CoV-2 infections: revised MS SBMB 2020 166. J Steroid Biochem Mol Biol 2020;202:105719

65 Santos RND, Maeda SS, Jardim JR, Nolasco Dos Santos $\mathrm{R}$, Setsuo Maeda S, et al. Reasons to avoid vitamin D deficiency during COVID-19 pandemic. Arch Endocrinol Metab 2020:S2359-39972020005006214.

66 Jolliffe DA, Stefanidis C, Wang Z, et al. Vitamin D metabolism is dysregulated in asthma and chronic obstructive pulmonary disease. Am J Respir Crit Care Med 2020;202:371-82.

67 Cipriani C, Romagnoli E, Pepe J, et al. Long-Term bioavailability after a single oral or intramuscular administration of 600,000 IU of ergocalciferol or cholecalciferol: implications for treatment and prophylaxis. J Clin Endocrinol Metab 2013;98:2709-15.

68 Martineau AR, Jolliffe DA, Greenberg L, et al. Vitamin D supplementation to prevent acute respiratory infections: individual participant data meta-analysis. Health Technol Assess 2019;23:1-44

69 Marcinowska-Suchowierska E, Kupisz-Urbańska M, Łukaszkiewicz $\mathrm{J}$, et al. Vitamin D Toxicity-A clinical perspective. Front Endocrinol 2018;9:55.

70 Liu G, Hong T, Yang J. A single large dose of vitamin D could be used as a means of coronavirus disease 2019 prevention and treatment. Drug Des Devel Ther 2020;14:3429-34.

71 Lewiecki EM. Vitamin D and COVID-19: is something better than nothing? Osteoporos Sarcopenia 2020;6:95-6.

72 Santos RND, Maeda SS, Jardim JR, et al. Reasons to avoid vitamin D deficiency during COVID-19 pandemic. Arch Endocrinol Metab 2020;28:S2359-39972020005006214. 